\title{
The Effect of Cr Concentration and Preparation Method on the Microstructure and Electrical Characterization of $\mathrm{SnO}_{2}$-Based Ceramics
}

\author{
Daniela Russo Leite*, Wanda Cecilia Las, Maria Aparecida Zaghete, \\ Mario Cilense, Jose Arana Varela \\ CMDMC-LIEC, Instituto de Química, UNESP \\ C.P. 355, 14800-900 Araraquara - SP, Brazil
}

Received: January 28, 2003; Revised: July 27, 2003

\begin{abstract}
This paper reports a study of the influence of $\mathrm{Cr}$ concentration and preparation method in the electrical conductivity and microstructure of $\mathrm{SnO}_{2}$-based powders doped with $\mathrm{Mn}$ and $\mathrm{Nb}$, prepared by an organic route (Pechini method) and a mixture of oxides. All the samples were compacted into discs and sintered at $1300{ }^{\circ} \mathrm{C}$ for $3 \mathrm{~h}$, resulting in ceramics with relative density varying between 81 and $99 \%$. The powders were morphologically characterized by X-ray diffraction and their specific surface area was determined by $\mathrm{N}_{2}$ adsorption/desorption isotherms. Electrical conductivity characterization indicated that the conductivity decreases as $\mathrm{Cr}$ concentration increases, probably due to $\mathrm{Cr}$ segregation at grain boundaries, which reduces grain size, increasing the number of resistive boundaries, thus limiting the passage of current.
\end{abstract}

Keywords: $\mathrm{SnO}_{2}$, conductivity, chromium

\section{Introduction}

Tin dioxide $\left(\mathrm{SnO}_{2}\right)$ is a n-type semiconductor whose tetragonal crystalline structure is similar to the rutile one ${ }^{1}$. This dioxide has many uses such as gas sensors, electrodes for electric glass melting furnaces, electro chromic devices, crystal displays, photo detectors, solar cells and protective coatings ${ }^{2-4}$. However the use of tin dioxide ceramics is limited due to poor densification during sintering caused by the dominance of non-densifying mechanisms for mass transport such as surface diffusion or evaporation condensation $^{5}$. These mechanisms promote grain coarsening of $\mathrm{SnO}_{2}$ leading to poor densification of this ceramics ${ }^{6}$.

Dense $\mathrm{SnO}_{2}$-based ceramics can be achieved by introducing dopants such as $\mathrm{MnO}_{2}{ }^{7}$ or by hot isostatic pressure processing ${ }^{8}$. Dopants with valence +2 can promote densification of $\mathrm{SnO}_{2}$ ceramics due to the formation of solid solution with the creation of oxygen vacancies ${ }^{9}$, according to:

$$
\mathrm{MO} \stackrel{\mathrm{SnO}_{2}}{\longrightarrow} M_{S n}^{\prime \prime}+V_{O}^{\bullet \bullet}+1 / 2 \mathrm{O}_{2(\mathrm{~g})}
$$

Dopants with valence +5 , such as $\mathrm{Nb}_{2} \mathrm{O}_{5}$, are added to $\mathrm{SnO}_{2}$ ceramics in small amounts to promote the substitu- tion of $\mathrm{Sn}^{+4}$ for $\mathrm{Nb}^{+5}$, leading to an increase of electronic conductivity in the $\mathrm{SnO}_{2}$ lattice ${ }^{10}$, according to:

$$
2 \mathrm{Nb}_{2} \mathrm{O}_{5} \stackrel{\mathrm{SnO}_{2}}{\longrightarrow} 4 \mathrm{Nb}_{S n}^{\cdot}+V_{S n}^{\prime \prime \prime \prime}+10 \mathrm{O}_{O}^{x}
$$

The addition of $\mathrm{Cr}_{2} \mathrm{O}_{3}$ in $\mathrm{SnO}_{2}$-based ceramics leads to a high non-linearity coefficient of $\alpha=41$ due the introduction of defects in the crystal lattice that are responsible for the formation of Schottky type potential barriers at the grain boundaries, enabling its use in varistors ${ }^{11}$. The introduction of $\mathrm{Cr}_{2} \mathrm{O}_{3}$ in the $\mathrm{SnO}_{2}$ lattice leads to the substitution of $\mathrm{Sn}^{+4}$ by $\mathrm{Cr}^{+3}$, according to the reaction:

$$
\mathrm{Cr}_{2} \mathrm{O}_{3} \stackrel{\mathrm{SnO}_{2}}{\longrightarrow} 2 \mathrm{Cr}_{S n}^{\prime}+\mathrm{V}_{O}^{\ddot{*}}+2 \mathrm{O}_{\mathrm{O}}+1 / 2 \mathrm{O}_{2(\mathrm{~g})}(3)
$$

Due to the large influence of $\mathrm{Cr}^{+3}$ in the electrical properties of $\mathrm{SnO}_{2}$-based ceramics, the effect of this ion on electrical conductivity in $\mathrm{Sn}-\mathrm{Mn}-\mathrm{Nb}$ systems, prepared by Pechini method and mixture of oxides, and its correlation with microstructural results were investigated in this work.

\section{Experimental Procedure}

The powders were prepared using the Pechini 
method $^{12-13}$ and mixture of oxides. The Pechini method consisted in the preparation of metallic citrates that were added to a solution of citric acid and ethylene glycol to form a polymeric resin. This resin was pre-calcined $\left(400{ }^{\circ} \mathrm{C} / 4 \mathrm{~h}\right)$ to eliminate organic material, de-aggregated by milling and calcined again $\left(500^{\circ} \mathrm{C} / 15 \mathrm{~h}\right)$ to eliminate residual organic material.

The raw materials were ethylene glycol (Merck), citric acid (Synth), tin chloride (Merck), manganese carbonate (Carlo Erba), niobium oxide (Puratronic), chromium nitrate (Vetec), ammonia solution (Merck) and nitric acid (Merck), tin dioxide (Merck), manganese oxide (Aldrich), chromium oxide (Vetec).

The powders were ground by a ball mill process in an alcohol media. The composition of the molar system was $(98.95-\mathrm{X}) \% \mathrm{Sn}+1.0 \% \mathrm{Mn}+0.03 \% \mathrm{Nb}+\mathrm{X} \% \mathrm{Cr}$, with $\mathrm{X}$ equal to $0.0,0.1,0.5$ and 0.7 , all in mole $\%$ (see Table 1).

Morphological characterization of obtained powders was done by X-ray diffraction (XRD; SIEMENS D-5000) while the specific surface area was measured by $\mathrm{N}_{2}$ adsorption/desorption isotherms (BET method; MICROMERITICS ASAP 2000).

The powders obtained were pressed into $8.0 \times 1.5 \mathrm{~mm}$ discs by uniaxial pressing (20 MPa), followed by isostatic pressing at $210 \mathrm{MPa}$. The discs were sintered at $1300^{\circ} \mathrm{C}$ for $3 \mathrm{~h}$ and slowly cooled down to room temperature. The relative densities were determined by the Archimedes method. Mean grain size was determined by analyzing the Scanning electron microscopy micrographies (SEM, TOPCOM $\mathrm{SM}-300)$, using the intercept method ${ }^{14}$. The discs for electrical conductivity measurements were subjected to a thermal treatment at $900{ }^{\circ} \mathrm{C}$ for $10 \mathrm{~h}$ and, after cooling, the plate surfaces were polished and platinum plated to insure a good electrical contact with the platinum tape of the disc holder. Four ohmic contacts were made at the sample using platinum paste. Values of resistance as a function of temperature were collected using a Hewlett-Packard 3457A multimeter connected to a computer.

\section{Results and Discussion}

The X-ray diffraction patterns of the compositions studied are shown in Fig. 1 for powders prepared by Pechini method and in Fig. 2 for mixture of oxides. It can be seen that the X-ray diffraction analysis indicates a single phase, the cassiterite, in all systems, as already observed in other reports ${ }^{1,5,9-11}$.

The values of specific surface area $\left(\mathrm{S}_{\mathrm{BET}}\right)$ and mean particle size $\left(\mathrm{D}_{\mathrm{BET}}\right)$ are given in Table 2 . An analysis of these data leads us to conclude that powders prepared by Pechini

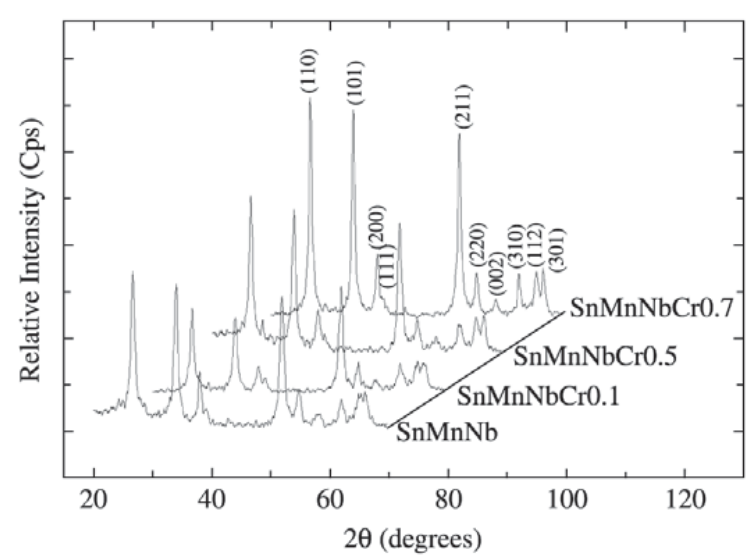

Figure 1. X-ray diffraction patterns of powders prepared by Pechini method, calcined at $500{ }^{\circ} \mathrm{C}$ for $15 \mathrm{~h}$.

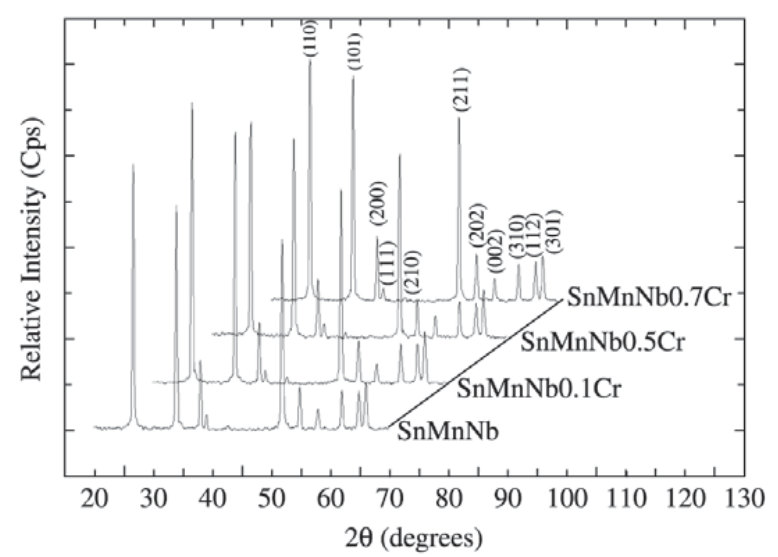

Figure 2. X-ray diffraction patterns of powders prepared by mixture of oxides.

Table 1. Molar system composition and nomenclature used for each system (Pch indicate Pechini method and Mox, mixture of oxides).

\begin{tabular}{cccccc}
\hline \multicolumn{3}{c}{ Composition of System } & \multicolumn{2}{c}{ Nomenclature } \\
\hline$\% \mathrm{Sn}$ & $\% \mathrm{Mn}$ & $\% \mathrm{Nb}$ & $\% \mathrm{Cr}$ & SnMnNbPch & SnMnNbMox \\
98.7 & 1.00 & 0.03 & - & SnMnNbCr0.1Pch & SnMnNbCr0.1Mox \\
98.6 & 1.00 & 0.03 & 0.10 & SnMnNbCr0.5Pch & SnMnNbCr0.5Mox \\
98.2 & 1.00 & 0.03 & 0.50 & SnMnNbCr0.7Pch & SnMnNbCr0.7Mox \\
98.0 & 1.00 & 0.03 & 0.70 & & \\
\hline
\end{tabular}


method showed to be finer and more reactive than those prepared by the mixing oxide method and that milling reduces the particle size of powders prepared by Pechini method. The particle size increases with $\mathrm{Cr}$ addition for both preparation methods, excepting the system without $\mathrm{Cr}$ prepared by mixture of oxides, probably due to a problem in milling. Table 3 presents the relative density of systems before and after sintering. According to this table, addition of 0.1 mole $\%$ of $\mathrm{Cr}$ presented better densification for both preparation methods. However, by increasing the $\mathrm{Cr}$ con- centration to 0.7 mole $\%$, the final density of the ceramics decreases substantially, which could be associated to the decrease of oxygen vacancy formation at the grain bound$\operatorname{ary}^{11}$.

The scanning electron microscopy micrographs are presented in Fig. 3a, 3b, 3c and 3d for ceramics prepared by Pechini method and in Fig. 3e, 3f, 3g and $3 \mathrm{~h}$ for mixture of oxides. In agreement with the relative density values shown in Table 3, it was found that the ceramics porosity increased with $\mathrm{Cr}$ concentration for both preparation methods. This

Table 2. Characterization of powders obtained by Pechini method and mixture of oxides, before and after milling: theoretical density, BET surface area and mean particle size.

\begin{tabular}{cccccccc}
\hline & \multicolumn{4}{c}{ Pechini method } & \multicolumn{2}{c}{ Mixture of oxides } \\
\hline System & $\mathrm{d}_{\text {theoretical }}$ & \multicolumn{2}{c}{$\mathrm{S}_{\mathrm{BET}}\left(\mathrm{m}^{2} / \mathrm{g}\right)$} & \multicolumn{2}{c}{$\mathrm{D}_{\mathrm{BET}}(\mu \mathrm{m})$} & $\mathrm{S}_{\mathrm{BET}}\left(\mathrm{m}^{2} / \mathrm{g}\right)$ & $\mathrm{D}_{\text {BET }}(\mu \mathrm{m})$ \\
& $\left(\mathrm{g} / \mathrm{cm}^{3}\right)$ & $\mathrm{WM}^{*}$ & $\mathrm{M} 8 \mathrm{~h}^{* *}$ & $\mathrm{WM}$ & $\mathrm{M} 8 \mathrm{~h}$ & $\mathrm{M} 8 \mathrm{~h}$ & $\mathrm{M} 8 \mathrm{~h}$ \\
$\mathrm{SnMnNb}$ & 6.919 & 36.6 & 44.1 & 0.024 & 0.020 & 8.50 & 0.102 \\
SnMnNbCr0.1 & 6.916 & 37.7 & 42.9 & 0.023 & 0.020 & 12.1 & 0.072 \\
SnMnNbCr0.5 & 6.902 & 36.1 & 38.6 & 0.024 & 0.023 & 9.92 & 0.088 \\
SnMnNbCr0.7 & 6.897 & 22.0 & 28.6 & 0.040 & 0.030 & 9.38 & 0.093 \\
\hline
\end{tabular}

$* \mathrm{WM}=$ without milling;

$* * \mathrm{M} 8 \mathrm{~h}=$ grinding for $8 \mathrm{~h}$ in a ball milling.

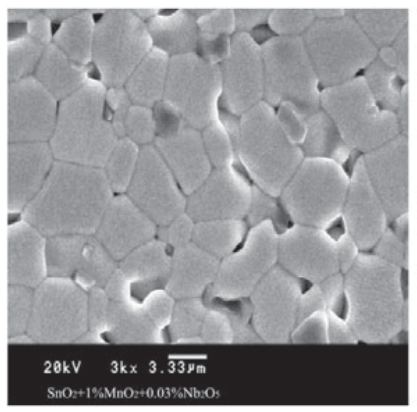

a)

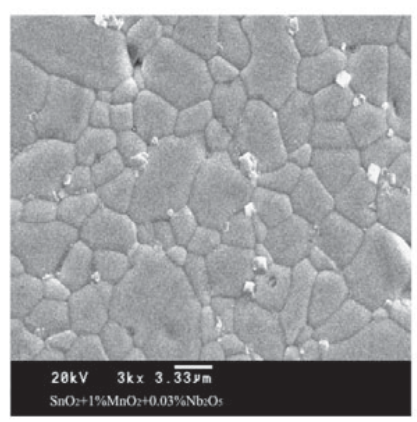

e)

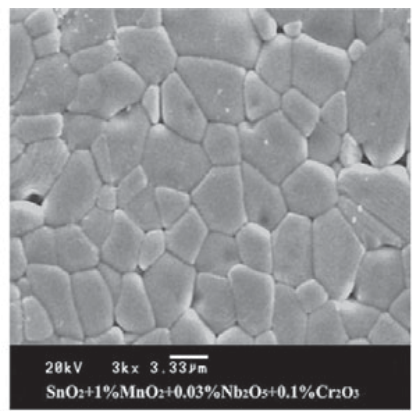

b)

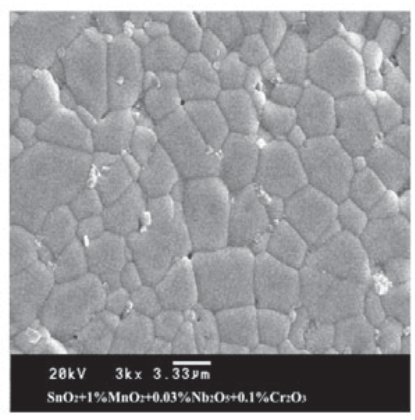

f)

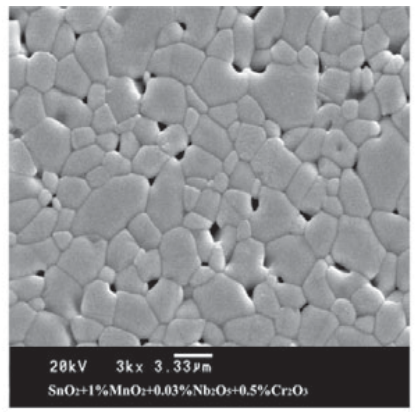

c)

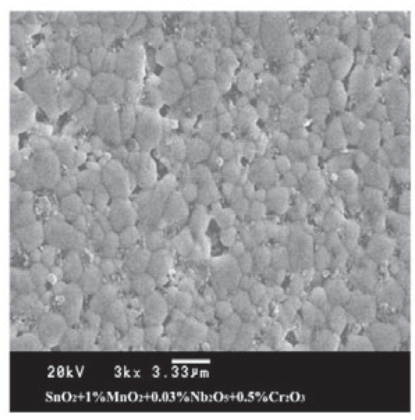

g)

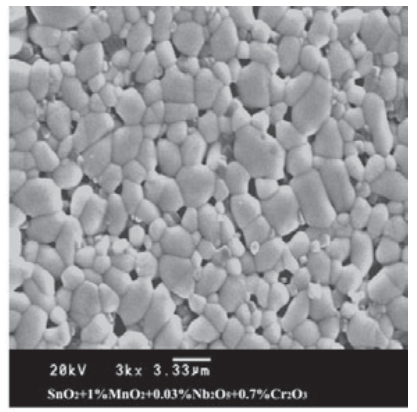

d)

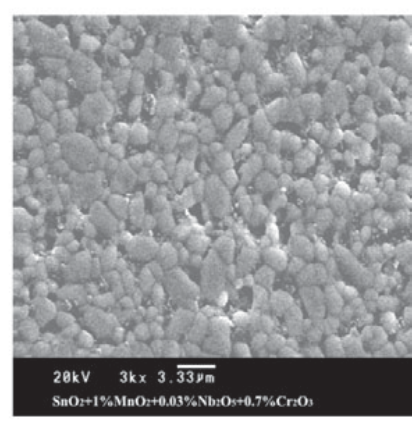

h)

Figure 3. a) SEM micrographs of sintered compacts at $1300{ }^{\circ} \mathrm{C}$ for $3 \mathrm{~h}$, prepared by Pechini method, with: (a) $0.0 \% \mathrm{~mol}$ of $\mathrm{Cr}$.; b) $0.1 \%$ mol of $\mathrm{Cr}$; c) $0.5 \% \mathrm{~mol}$ of $\mathrm{Cr}$; d) $0.7 \% \mathrm{~mol}$ of $\mathrm{Cr}$; and prepared by mixture of oxides, with: e) $0.0 \% \mathrm{~mol} \mathrm{of} \mathrm{Cr}$; f) $0.1 \% \mathrm{~mol} \mathrm{of} \mathrm{Cr}$; $\mathrm{g}$ ) $0.5 \% \mathrm{~mol}$ of $\mathrm{Cr}$; h) $0.7 \% \mathrm{~mol}$ of $\mathrm{Cr}$. 
increase in porosity is probably due to the segregation of $\mathrm{Cr}$ at the grain boundary region, impairing mass transport during sintering. The ceramics systems are characterized by heterogeneous grain size distribution.

Table 4 shows the variation of $\mathrm{Cr}$ concentration on mean grain size. Increasing $\mathrm{Cr}$ concentration leads to microstruc-

Table 3. Relative density $\left(\mathrm{d}_{\mathrm{R}}\right)$ of green compacts and sintered compacts at $1300{ }^{\circ} \mathrm{C}$ for $3 \mathrm{~h}$.

\begin{tabular}{ccccc}
\hline & \multicolumn{2}{c}{ Pechini method } & \multicolumn{2}{c}{ Mixture of oxides } \\
\hline System & Green & Sintered & Green & Sintered \\
& $\mathrm{d}_{\mathrm{R}}(\%)^{*}$ & $\mathrm{~d}_{\mathrm{R}}(\%)$ & $\mathrm{d}_{\mathrm{R}}(\%)$ & $\mathrm{d}_{\mathrm{R}}(\%)$ \\
$\mathrm{SnMnNb}$ & 50.6 & 91.8 & 53.5 & 98.6 \\
$\mathrm{SnMnNbCr} 0.1$ & 49.5 & 98.3 & 54.1 & 99.4 \\
$\mathrm{SnMnNbCr} 0.5$ & 50.6 & 94.6 & 54.0 & 87.2 \\
SnMnNbCr0.7 & 51.9 & 88.5 & 53.7 & 81.0 \\
\hline
\end{tabular}

* The relative density was calculated considering the theoretical density of the system.

$* * \mathrm{P}=100-\mathrm{d}_{\mathrm{R}}$

Table 4. Mean grain size $\left(\mathrm{S}_{\text {grain }} / \mu \mathrm{m}\right)$ of systems sintered at $1300{ }^{\circ} \mathrm{C}$ for $3 \mathrm{~h}$.

\begin{tabular}{ccc}
\hline System & $\mathrm{S}_{\text {grain }} \pm$ standart deviation $(\mu \mathrm{m})$ \\
\hline & Pechini Method & Mixture of Oxides \\
SnMnNb & $4.5 \pm 1.4$ & $3.7 \pm 1.6$ \\
SnMnNbCr0.1 & $4.4 \pm 1.6$ & $3.6 \pm 1.5$ \\
SnMnNbCr0.5 & $2.8 \pm 1.2$ & $1.8 \pm 0.6$ \\
SnMnNbCr0.7 & $2.1 \pm 0.8$ & $1.8 \pm 0.6$ \\
\hline
\end{tabular}

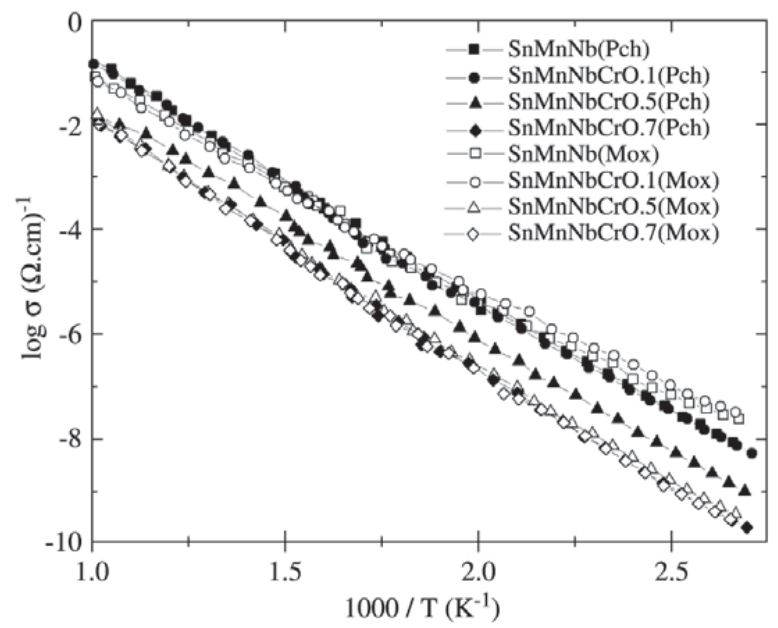

Figure 4. Electrical conductivity as a function of temperature of system $\mathrm{SnMnNbCrx}$, with $0 \leq \mathrm{x} \leq 0.7 \% \mathrm{~mol}$, sintered at $1300{ }^{\circ} \mathrm{C}$ for $3 \mathrm{~h}$.

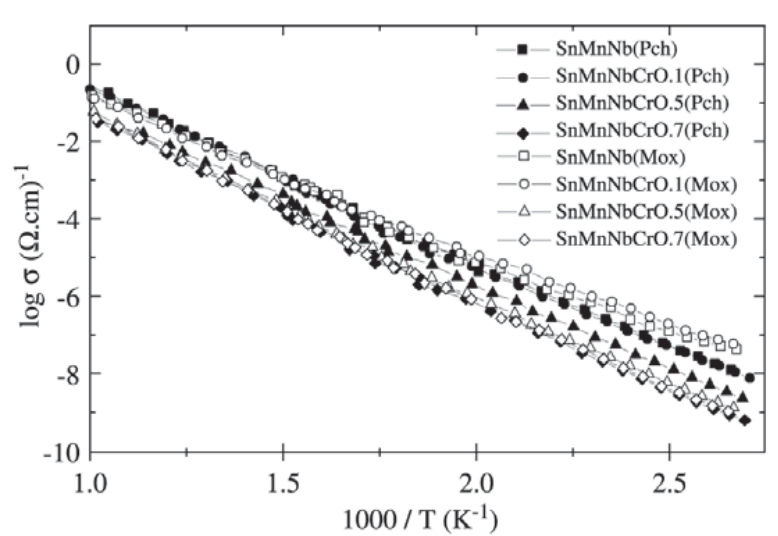

Figure 5. Electrical conductivity normalized to grain size as a function of temperature of system SnMnNbCrx, with $0 \leq \mathrm{x} \leq 0.7 \% \mathrm{~mol}$, sintered at $1300{ }^{\circ} \mathrm{C}$ for $3 \mathrm{~h}$.

tures with decreasing mean grain size for both preparation methods. The decrease in mean grain size could be associated to segregation in the grain boundaries.

The dependence of the conductivity on the temperature is shown in Fig. 4. The conductivity decreases with decreasing temperature, what is expected for this semiconductor oxide. Normalizing these curves to grain size (Fig. 5), a significant decrease in conductivity for ceramics doped with $\mathrm{Cr}$ concentration higher or equal than 0.5 mole $\%$ was observed. Also, this is probably due to $\mathrm{Cr}$ segregation at the grain boundaries, which reduces mean grain size, so that the number of resistive boundaries increases, limiting the passage of current.

\section{Conclusion}

The relative density results agree with the scanning electron microscopy micrographs. The ceramic microstructure is strongly dependent on the $\mathrm{Cr}$ concentration. The $\mathrm{Cr}$ forms a phase segregated at the grain boundary and appears to control the sintering and grain growth rates. Thus, excess of it in the chemical composition leads to the formation of porous microstructure, deleterious for electrical conductivity.

\section{Acknowledgments}

The financial support of this research by FAPESP, CNPq and CAPES is gratefully acknowledged.

\section{References}

1. Jarzebski, Z.M.; Marton, J.P. J. Electrochem. Soc., v. 123, p. 299C-310C, 1976.

2. Chopra, K.L.; Major, S.; Pandya, P.K. Thin Solid Films, 
v. 102 , p. 1, 1983.

3. Fagan, J.G.; Amarakoon, V.R.W. Am. Ceram. Soc. Bull., v. 72, p. 119-129, 1993.

4. Olivi, P.; Souza, E.C.P.; Longo, E.; Varela, J.A.; Bulhões, L.O.S. J. Electrochem. Soc., v. 140, p. L81, 1993.

5. Varela, J.A.; Longo, E.; Barelli ,N.; Tanaka, A.S.; Mariano, W.A. Cerâmica, v. 31, p. 241-245, 1985.

6. Duvigneaud, P.H.; Reihard, D. in Science of sintering, P. Vicenzini, ed. Ceramurgia Srl., Faenza, Italy, p. 287-292, 1980.

7. Zuca, S.; Terzi, S.; Zaharescu, M. J. Mater. Sci., v. 26, p. $1673,1991$.
8. Park, S.J.; Hirota, K.; Yamamura, H. Ceramics International, v. 10, p. 115-116, 1984.

9. Pianaro, S.A.; Bueno, P.R.; Longo, E.; Varela, J.A. J. Mater. Sci. Lett., v. 14, p. 692-694, 1995.

10. Wang, Y.J.; Wang, J.F.; Li, C.P.; Chen, H.C.; Su, W.B.; Zhong, W.L.; Zhang, P.L.; Zhao, L.Y. J. Mater. Sci. Lett., v. 20, p. 19-21, 2001.

11. Pianaro, S.A.; Bueno, P.R.; Longo, E.; Varela, J.A. Ceramics International, v. 25, p. 1-6, 1999.

12. Pechini, M.P. U. S. Patent, n. 3330697, 1967.

13. Besso, M.M. U. S. Patent, n. 3123120, 1965.

14. Mendelson, M.I. J. Am. Ceram. Soc., v. 52, p. 443, 1969. 